\title{
THE WHORF HYPOTHESIS AND LANGUAGE MANIPULATION IN DYSTOPIAN LITERATURE
}

\author{
CMansurov R., ORCID: 0000-0001-5666-8374, Uzbekistan State University of World Languages, \\ Tashkent, Uzbekistan, Mansurovr92@gmail.com \\ ГИПОТЕЗА ВОРФА И МАНИПУЛЯЦИИ ЯЗЫКА \\ В ДИСТОПИЧЕСКИХ ПРОИЗВЕДЕНИЯХ
}

\section{(CМансуров Р. Д., ORCID: 0000-0001-5666-8374, Узбекский государственный университет мировых языков, г. Ташкент, Узбекистан, Mansurovr92@gmail.com}

Abstract. Problem of language manipulation reflected in dystopian fiction suggests certain changes that drastically influence mentality of people. Deeper analysis of dystopian texts such as 'Cloud Atlas', 'We', 'Nineteen Eight-Four', 'Brave New World' and other works reveal that the one, who controls language, controls the mind of people. Language as such carries within itself many meanings related to culture, values, beliefs and many more, and thus limiting the open expression in language restricts access to that information that is stored behind words. This matter is touched by The Whorf hypothesis.

Аннотащия. Проблема манипуляции языка, затронутая в дистопических произведениях, таких как «Облачный Атлас», «Mbl», «Дивнылй Новый Мир», «1984» и в других произведениях, их глубокий анализ дает нам понять то, что кто контролирует язык, тот контролирует сознание людей. Слова языка, согласно гипотезы Ворфа (Сапира-Ворфа), не только несут при себе фиксированные значения, но также культурные, религиозные и другие ценности (маркеры), ограничение языка (слов) может повлиять на сознание и ограничить восприятие этой информации.

Keywords: dystopia, Whorf-Sapir hypothesis, nineteen eighty-four, newspeak.

Ключевые слова: дистопия, гипотеза Сапира-Ворфа, 1984, новояз.

Language, when comes applied to the genre dystopia can take different shapes and forms. It is thanks to the possibility with time manipulation; authors express their view by disrupting traditional patter of the language or accepted form of the language. Sometimes authors move in time, thus while describing the changed future, they on their own should describe the language which have changed. If we think about it, we understand that language is not a static thing. It is always in a movement. Its movements are result of our choices. People usually shape the language. But in case of dystopian literature, language functions as a tool of limitation, while in utopian literature it functions in vise versa form. Thus language is shaped not by people but by political interests.

According to Myra Barnes “ ... all dystopian languages technically belong to Whorf” [1]. The Whorf hypothesis (sometimes called the Whorf-Sapir hypothesis) claims that language strongly influences perceived reality and therefore the 'real world' is, in fact, a linguistic construct. In a similar way, post-structuralism has cast doubt upon classical notions of truth, reality, meaning and knowledge. If meaning (the signified) is always an unstable product of words (signifiers) there is little room left for a determinable truth. If reality is a mere by-product of discourse then all we 
can know is discourse itself. This has been called the 'prison of discourse' [2, p. 97] by critics opposed to such an extreme version of post-structuralism.

The prison of discourse model of reality is fully subscribed to by the image of political Party in Nineteen Eighty-Four. In his novel the writer used the Party official O'Brien declare the following, in terms which some post-structuralists would find hard to disagree with:

You believe that reality is something objective, external, existing in its own right. You also believe that the nature of reality is self-evident. When you delude yourself into thinking that you see something, you assume that everyone else sees the same thing as you. But I tell you, Winston, that reality is not external. Reality exists in the human mind, and nowhere else. Not in the individual mind, which can make mistakes, and in any case soon perishes: only in the mind of the Party, which is collective and immortal. Whatever the Party holds to be truth, is truth [3, p. 197-245].

Whereas people generally strive to expand their lexicon, the government in Nineteen EightyFour actually aims to cut back the Newspeak vocabulary. One of the Newspeak engineers says, "[we're] cutting the language down to the bone ... Newspeak is the only language in the world whose vocabulary gets smaller every year". By manipulating the language, the government wishes to alter the public's way of thinking. This can be done, psychologists theorise, because the words that are available for the purpose of communicating thought tend to influence the way people think. Linguist Benjamin Lee Whorf was a firm believer in this link between thought and language, and he theorised that "different languages impose different conceptions of reality [4]". So, when words that describe a particular thought are completely absent from a language, that thought becomes more difficult to think of and communicate. For the Inner Party, the goal is to impose an orthodox reality and make heretical thought ('thoughtcrime') impossible. "In the end we shall make thoughtcrime literally impossible", explains the Newspeak engineer, "because there will be no words in which to express it".

Certainly, in Nineteen Eighty-Four, "[media information] does control some of the ways in which [people] think about and assess the world". The Party is interested in masking the truth, and so the media manipulates language to present a distorted reality. As Orwell says in his essay Politics and the English Language, "Political language ... is designed to make lies sound truthful and murder respectable, and to give an appearance of solidity to pure wind" [5, p. 143-150]. In the novel, these lies are quite obvious. For example, the media (controlled by the Party, of course) continually refers to the Ministries of Truth, Peace, Love, and Plenty. In reality, however, the Ministry of Truth is concerned with the falsification of records, and the Ministry of Peace deals with warfare. The Ministry of Love is "the really frightening one" as it is essentially a place for the questioning and torturing of suspected criminals. The Ministry of Plenty makes up economic figures to convince the public that the economy is in good shape, even though there are great shortages of all commodities due to the war. Although the irony in the titles is blatantly obvious, Orwell is making a point about how the media can use language to mask the truth.

Even small talks that take place between the main hero and other characters tend to be limited, and the new edition of the dictionary which is being worked on to be published includes less undesirable words. We can see here, that while not knowing the word freedom, people would not try to achieve it. In 1984 each new edition of dictionary contains less and less words that have contradictory meaning to political party's interest. With each edition main political party removes a politically active word, thus removing all desire of people to act against it. Even the news and documentation falls into the hand of political machine, in this sense language is a tool of oppression.

Orwell's novel carries a well-founded warning about the powers of language. It shows how language can shape people's sense of reality, how it can be used to conceal truths, and even how it 
can be used to manipulate history. Language is one of the key instruments of political dominations, the necessary and insidious means of the 'totalitarian' control of reality [6].

While language in the traditional sense can expand horizons and improve our understanding of the world, Orwell's novel demonstrates that language, when used in a maliciously political way, can just as easily become "a plot against human consciousness" [7, p. 181].

Lewis and Moss believe that "the tactic is to obliterate history so that centers of opposition cannot grow" [8, p. 45-57]. Orwell shows evidence that this tactic is working: even the main character, who knows exactly what is going on with the falsification of documents, has trouble recalling who Oceania is really at war with at the present. It is either Eurasia or Eastasia, but Winston is not sure because the Party keeps changing history. This nagging doubt eats away at Winston until he no longer knows what reality is; by the end of the novel, he is willing to accept the Party's reality.

This reading of the slogan 'never think what cannot be said' hinges on the meaning of the word 'cannot'. In his essay on Newspeak, Orwell says that: "It would have been possible, for example, to say Big Brother is ungood. But this statement, which to an orthodox ear merely conveyed a self-evident absurdity, could not have been sustained by reasoned argument, because the necessary words were not available” [3, p. 197-245].

However, Newspeak forms a very small element of control in Nineteen Eighty-Four, the majority of which is given over to describing other tools of state oppression (telescreens, Thought Police, etc.). What is regulated, therefore, is less language in its abstract form than language in actual usage - that is, discourse. In other words, state intervention occurs, at least initially, to censor what is said rather than what can be said. Hence, the need to declare some words 'non-words'. What the state presumably hopes is that by forcing its citizens to self-regulate their own speech acts this will ultimately alter language itself — the mixture of words and the rules (grammar) for combining those words into sentences. This is similar to certain strands of feminism which believe, for example, that discouraging the use of 'man' to mean 'humanity' has the potential to make philosophy and science less male-centered. Similarly, anti-racist philosophy is in favor of restrictions (sometimes legal restrictions) not only on obviously offensive terms for ethnic minorities, but also expressions such as 'blackmail' with its negative connotations of 'black'. ${ }^{2}$

1984 is not the only example which can stand outs with this, alongside with it can study the novel We by Yevgeniy Zemyatin as one of classics, Brave New World also touches the matter of language and its manipulation, Fahrenheit 451 directly fits to this category as the language is twisted by social conditions, and poetry and beauty are banned as something not fitting the time.

Modern writes such as Luis Lowry with his work "Giver", touches the matter of language is new society where emotions are banned, alongside with it words that contain emotional charge, such as 'love' , 'hate', 'death', 'pride', 'killing' and many others. The language is this sense works for social order, and tries to limit the sharp edges of the language which might trigger emotional reaction, as emotions are considered as root of all evil in the novel.

David Mitchell also stands out with his famous work 'Cloud Atlas' where we might find story fitting the genre of dystopia. It is called "Orison of Sonmi-451", story touches the fate of genetically engineered clone Sonmi-451, who stops to consume her drug that suppresses her mental skills. For her surprise, she finds out that she and other clones are limited with their language. They (clones) were genetically engineered to serve in fast food chain, and their vocabulary relied only to fit into this category. As she got free from suppressing drugs, she starts to work on her education by finding means to do so. She finds 'sony' (video player) with old film in it. And the film was about

\footnotetext{
${ }^{2}$ Feminism's and anti-racism's desire to control language problematises Meyers's definition of dystopias as restricting language. Is it possible to categorise 'good' and 'bad' restrictions?
} 
an old man trapped in retirement home, and this man seeks way out, soon Sonmi realizes that she is trapped here in this food chain too. She seeks way out, and eventually understands that all clones are just slaves. Even the word slave is banned; the fact of its existence was there. She was the slave, and she was supposed to be remaining there consuming her drug and serving consumers until her expiry date reaches the end. Limited language made this close incapable of thinking beyond their daily tasks.

Also with such manipulations new words happen to be seen in dystopian novels. Such words as 'soap' as chemical drug used to suppress mental capacity in Cloud Atlas, thoughtcrime as new word from 1984, fabricants as substitute word for cloned slaves, and many others.

Manipulation of language is evidently seen in Cloud Atlas, chapter 5 that is called "An Orison of Sonmi-451" interview of Sonmi-451 and representative of the government who is supposed to interview her before she receives capital punishment. There we will come to find new words that might trigger our curiosity. Brief paragraph from original text will be analyzed to prove the point.

It is dialogue between Archivist and Sonmi-451.

Archivist: "A more metaphysical question ... were you happy, back in those days? Sonmi-451: Before my ascension, you mean? If, by happiness, you mean the absence of adversity I and all fabricants are the happiest stratum in corpocracy as genomicists insist. However, if happiness means the conquest of adversity or a sense of purpose, or the xercise of one's will to power, then of all Nea So Copros's slaves we surely are the most miserable. I endured drudgery but enjoy it no more than yourself.

"Archivist: Slaves, you say? consumers, the very word slave is abolished throughout Nea So Copros!

Sonmi-451: Corpocracy is built on slavery, whether or not the word is sanctioned. Archivist, I do not wish to offend you, but is your youth dewdrugged or genuine? I am puzzled. Why has my case been assigned to an apparently inxperienced corpocrat?" [9].

The word ascension does have certain meaning "The degree of elevation of an object", and applied text from above suggests that as a slave Sonmi-451 objectifies herself, as language makes her do so. She is not human, even though she has all traits of living human being, by society she was genetically engineered to be slave. Thus, even after herself-education and she couldn't free herself from the shackles of language limitations.

Other future elements are reflected in text too, such as the word "consumers" equal to the word citizens. In the future reflected in the novel, all should be consumers, production rate shouldn't drop. To do so, even the just calling someone they remind to that citizen to consume. Certain relation link can be seen between these comparisons; Aldus Huxley also touched the magnificent value of the word consumers in his "Brave New World" where consumerism is key idea.

The word fabricants stand as substitute for the word slaves, while derogatory meaning containing word perished, other neutral word was coined. Sense and meaning are the same of these two words "fabricant" "slave".

xercise, inxperienced these words carry the futuristic transformation of the language too, as $e$ letter dropped there and these examples are not limited with 2 mentioned above.

In Brave New World, the World State has created stability by genetically engineering its citizens to be happy with who they are and what they do. People are not born, they are decanted in hatcheries; and medically and psychologically manipulated so that they have just the right intelligence, strength, and attractiveness to fill the social and economic positions that will need to be filled. 
These decanted children are raised and indoctrinated in conditioning centers so that, by the time they are old enough to work, their only ambitions are to perform the tasks for the positions they were raised to fill. Their loyalty is to the state and to continued community and stability. Family and its language are obsolete concepts.

But it's more sinister than simple obsolescence. The World State maintains stability by obliterating individual personality. People of the same caste are largely identical by design. Very few personality traits are left to chance, and people are encouraged (through promiscuity) not to form strong bonds with other individuals, word love would trigger certain shiver to most citizens in Brave New World.

There is no stronger bond than family, and family is a major factor in self-identification. And what better way to eliminate family than to make it a dirty word?

So in Brave New World, we see a reversal from what we know today. People are raised to think of the language of sexual promiscuity is normal and expected and accepted, while the language of the family is obscene. This manipulation of the language is just another way that the World State controls citizens and maintains stability.

$R-13, O-90, D-503, I-330$ this mentioned letter containing numbers might not be understood by people who have not read the novel "We", for these numbers and letters stand as names of main characters of the novel. In the futuristic state, where One State has reached total equality, people no longer have name that could contain cultural background. Thus language in "We" is transformed one. Like in Brave New World, here we face the same problem of language transformation when we study the word family. Family as such is nonexistent word, love is something odd, and for they (main characters) in the novel cannot explain the feelings they are having. Even the word dreaming carries negative connotation by which it loses its great meaning.

"But we, people of today, we know all too well that dreaming is a serious mental disease" [10].

Though the word dreaming is marked as sickness, One State dreams to spread its ideas to other planets, by building the spaceship "Integral", contradicting to its own ideals. Thus is language irony within the novel.

Other example can be taken from Ray Bradbury's - "451-Fahrenheit" where we are introduced to the word "fireman", which has quite different meaning than what it means nowadays. This transformation of the word once more proves to be prof of language manipulation. The word "fireman", identifies the job of fire starter who sets books, literature on fire, totally contradicting to initial meaning of the word "fireman". These firemen set books, literature and other sources of education on fire, for the new government there finds that old language might not fit into its interests. Thus they want to destroy classical examples of literature, for these works are fine carriers of the free language.

Examples found above, suggests that Whorf's hypothesis works in fictional dystopian literature, presenting itself as a tool of implicid control over the minds of people. Omitting undesirable words from language, thus being able to be singual source of "truth".

\section{References:}

1. Booker, M. K. (1995). The dystopian impulse in modern literature: Fiction as social criticism.

2. Sarup, M. (1993). An Introductory Guide to Post-structuralism and Post-modernism. Harvester Wheatsheaf. Hemel Hempstead.

3. Orwell, G. (2009). Nineteen eighty-four. Everyman's Library.

4. Myers, D. G. (1986). Psychology. $4^{\text {th }}$ ed. Holland, Worth Publishers. 
5. Orwell, G. E. O. R. G. E. (1949). Nineteen Eighty-Four. London, Secker \& Warburg.

6. Rai, A. (1988). Orwell and the politics of despair: A critical study of the writings of George Orwell. Cambridge, Cambridge University Press.

7. Rahv, Ph. The Unfuture of Utopia in Nineteen Eighty-Four, Text, Sources, Criticism.

8. Chilton, P., \& Aubrey, C. (1983). Nineteen eighty-four in 1984: autonomy, control and communication. Comedia Publishing Group.

9. Mitchell, D. (2008). Cloud Atlas: A Novel. Random House.

10. Zamyatin, Ye. (1924). We. Translation Gregory from Zilboorg. New York, Duton, 248.

\section{Список литературы.:}

1. Booker M. K. The dystopian impulse in modern literature: Fiction as social criticism. 1995.

2. Sarup M. An Introductory Guide to Post-structuralism and Post-modernism. Harvester Wheatsheaf // Hemel Hempstead. 1993.

3. Orwell G. Nineteen eighty-four. Everyman's Library, 2009.

4. Myers D. G. Psychology. 4th ed. Holland: Worth Publishers, 1986.

5. Orwell G. Nineteen Eighty-Four. London: Secker \& Warburg, 1949.

6. Rai, A. (1988). Orwell and the politics of despair: A critical study of the writings of George Orwell. Cambridge: Cambridge University Press.

7. Rahv, Ph. The Unfuture of Utopia in Nineteen Eighty-Four: Text, Sources, Criticism.

8. Chilton P., Aubrey C. Nineteen eighty-four in 1984: autonomy, control and communication. Comedia Publishing Group, 1983.

9. Mitchell D. Cloud Atlas: A Novel. Random House, 2008.

10. Zamyatin Ye. We. Translation Gregory from Zilboorg. New York: Duton, 1924. 248 p.

Работа поступила

в редакцию 10.04.2019 2.
Принята к публикации 15.04.2019 2.

Ссылка для циитирования:

Mansurov R. The Whorf Hypothesis and Language Manipulation in Dystopian Literature // Бюллетень науки и практики. 2019. Т. 5. №5. С. 481-486. https://doi.org/10.33619/2414$2948 / 42 / 71$.

Cite as $(A P A)$ :

Mansurov, R. (2019). The Whorf Hypothesis and Language Manipulation in Dystopian Literature. Bulletin of Science and Practice, 5(5), 481-486. https://doi.org/10.33619/2414$2948 / 42 / 71$ 